\title{
BULGARIAN-SERBIAN RAPPROCHEMENT IN 1904 AS THE BASIS FOR THE UNIFICATION OF THE SOUTH SLAVS: REMARKS ON BONCHO BOEV'S FEDERALIST CONCEPTS ${ }^{1}$
}

\author{
Krzysztof Popek \\ http://orcid.org/0000-0001-5864-5264 \\ Jagiellonian University, Cracow (Poland)
}

\begin{abstract}
The article discusses the federalist concepts of the Bulgarian economist Boncho Boev, formulated during the Bulgarian-Serbian rapprochement in 1904. The creation of a South-Slavic State would take place through the economic integration of Serbia and Bulgaria, which, by improving their economic position, would simultaneously strengthen their political situation and join Macedonia. Boev's views are presented on the basis of speeches given during the Student Balkan Congress in Sofia on 6-8 March (22-24 February old style) 1904, and subsequently published in the Journal of the Bulgarian Economic Society as "Посещението на Сръбски крал и сръбско-българското сближение" [The Visit of the King of Serbia and the Serbian-Bulgarian Rapprochement] and “Балканската федерация като идеал на сръбско-българската младеж” [The Balkan Federation as the Ideal of the Bulgarian-Serb Youth].
\end{abstract}

Keywords: Bulgaria, Serbia, Bulgarian-Serbian relations, Balkan federalism, South Slavs.

\section{INTRODUCTION}

The Bulgarian-Serbian relations in the second half of the $19^{\text {th }}$ and early $20^{\text {th }}$ Century were not friendly in many aspects, among others in the field of politics. While in the 1860s there had been projects of rapprochement between these two Slavic nations, such as the Bulgarian Leagues in Belgrade or the Yugoslav Tsardom, in later years more and more areas of conflict appeared. Historians take the year 1878 and the Treaty of Berlin as the symbolic date of the end of the romantic period in the rela-

1 This paper is a part of an OPUS 13 project, funded by the National Science Centre in Cracow, called "Between two congresses in Prague: relations among the Slavs in Central and South-East Europe in 1848-1908" (2017/25/B/HS3/00240). 
tions among the Balkan nations. The establishment of the Bulgarian state, initially within borders that included lands which the Serbs regarded as ethnically Serbian, started the growing conflict. The disagreement about spheres of influence in and the character of Macedonia, which found itself within the borders of the collapsing Ottoman Empire, meant that the closely connected nations could not find a common ground. However, even at that time there were some persons who went against the mutual animosity and searched for areas in which agreement could be found. It was in this spirit that in 1904 the Bulgarian economist Boncho Boev proposed a project of Bulgarian-Serbian unification, expanding on its economic aspects in response to the expectations of the liberal circles in South Slavic states. ${ }^{2}$

The Balkan unionism in the $19^{\text {th }}$ Century was analyzed not only by the Balkan researchers as Leften Stavros Stavrianos, ${ }^{3}$ Ivan Ormandzhiev, ${ }^{4}$ Tsetan Stoyanov, ${ }^{5}$ or Milcho Lalkov ${ }^{6}$ but also historians from Central Europe as Elżbieta ZnamierowskaRakk, ${ }^{7}$ Irena Stawowy-Kawka ${ }^{8}$ or Árpád Hornyák. ${ }^{9}$ Polish interests in this problem should not come as a surprise - one of the leading figure of the Polish diaspora in the $19^{\text {th }} \mathrm{c}$. Prince Adam Jerzy Czartoryski was the author of the federal concept of the Balkan nations. ${ }^{10}$ There were more works about the Yugoslavism, however, the Bulgarian issues were in a margin of these concepts. ${ }^{11}$ It is important that the most important works are quite old - they were written in the first half of the $20^{\text {th }}$ Century.

2 E. Znamierowska-Rakk, "Z dziejów bałkańskich koncepcji federacyjnych (od schyłku XVIII w. do końca I wojny światowej),” Studia z Dziejów Rosji i Europy Środkowo-Wschodniej 2000, vol. 35, p. 15.

3 L.S. Stavrianos, Balkan Federation: A History of the Movement toward Balkan Unity in Modern Times, Northampton 1944.

4 И. Орманджиев, Федерация на балканските народи. Идеи и пречки, София 1947.

5 Ц. Стоянов, Федеративната идея в българо-сръбските отношения, София 1919.

6 М. Лалков, От надежда към Разочерование, идеята за федерация в балканския югоизток, София 1994.

7 E. Znamierowska-Rakk, "Z dziejów bałkańskich koncepcji federacyjnych (od schyłku XVIII w. do końca I wojny światowej)," pp. 5-23.

8 I. Stawowy-Kawka, "Miejsce Macedonii w koncepcjach federacji bałkańskiej" [in:] $K u$ zjednoczonej Europie. Studia nad Europa Środkowa i Poludniowo-Wschodnia w XIX i XX wieku, eds. I. Stawowy-Kawka, W. Rojek, Kraków 1997, pp. 83-98.

9 Á. Hornyák, "The Balkan Federation 1866-1948," Bulgarian Historical Review 2007, vol. 35, no. $1-2$, pp. 217-232.

10 The most valuble works about the Czartoryski's federal conceptions were written by Jerzy Skowronek (Sprzymierzeńcy narodów bałkańskich, Warszawa 1983), Antoni Cetnarowicz ("Wkład Polaków w kształtowaniu się idei jedności wśród Słowian południowych," Studia Polono-Danubiana et Balcanica 1995, vol. 7, pp. 33-44), and Piotr Żurek (Czarnogórcy i Serbowie w rosyjskiej polityce księcia Adama Jerzego Czartoryskiego (1802-1806), Kraków 2009).

11 В. Енчев, “Югославската идея сред южните славяни през XIX и XX век," Актуални проблеми, аспекти и перспективи на международните отнотения 2010, т. 2, pp. 318-333; See also: М. Екмечић, Стварање Југославије 1790-1918, Београд 1989; Ф. Шишић, Југословенска мисао. Историја идеје југословенског народног уједињења и ослобођења од 1790-1918, Београд 1937; A. Giza, Idea jugoslawizmu w latach 1800-1918, Szczecin 1992. 


\section{BONCHO BOEV}

In the book България ХХ век: Алманах (Bulgaria 20 ${ }^{\text {th }}$ Century: Almanac), edited by Filip Panayotov, Boncho Nenkov Boev is described as "a typical representative of the first post-revival generation of the Bulgarian intellectual and economic elite". ${ }^{12}$ He was born in 1859 in the town of Kotel, where he received his primary education, which he continued in the renowned Aprilov National High School in Gabrovo. He then left for Russia and attended the seminary in Odessa. He gave up the career of an Orthodox priest and in 1877 he started a course in law at the University of Moscow, during which he also trained in Germany. After returning to Bulgaria in 1885, he was employed as a clerk in the Ministry of Finance, where he was later promoted to the head of the Direct Tax Department. In the second half of the 1880s and the first half of the 1890s he was responsible for important reforms, such as introducing a system of tax control and the end of collecting taxes in kind. In 1894-1906, Boev taught finance and statistics in the Higher School in Sofia (present day University of Sofia), and during this time he joined the Bulgarian Literary Society (present-day Bulgarian Academy of Sciences) and established the Bulgarian Economic Society, of which he was the chairman in 1901-1906. In 1901 he started to publish the society's press organ-Journal of the Bulgarian Economic Society, of which he was the editor-inchief. The pinnacle of Boev's career was the position of the Governor of the Bulgarian National Bank in 1906-1908.

In 1908 he finished his career in the public sector and went on to pursue trade and private banking. First, he became involved in developing the cement industry, then he was a board member of Girdap - the first privately owned Bulgarian bank, the third largest one in the country prior to 1912 (after the Bulgarian Commercial Bank and the Bulgarian Credit Bank). During WWI Girdap, as well as Boev, who occupied important positions in the bank, cooperated closely with the government. After the war, as a result of reckoning with politicians responsible for war losses, he was sentenced to prison, along with other members of the Girdap board. Boev was arrested for eight months, but quickly was acquitted. After his release, he worked on paying off the bank's debts, as a result of which he lost most of his estate and got into serious debt, which continued to be paid off by his family after his death. Boncho Boev died in 1934 in Sofia. ${ }^{13}$

12 България 20 век. Алманах, съст. Ф. Панайотов, София 1999, р. 236.

13 Р. Аврамов, Комуналният капитализъм. Из българското стопанско минало, т. 2, София 2007, pp. 508-525; Голяма енциклопедия България, т. 1: А-Бъл, ред. В. Гюзелев, София 2011, p. 310 . 


\section{BULGARIAN-SERBIAN RAPPROCHEMENT IN 1904}

The first years of the $20^{\text {th }}$ Century were rife with events which led to a profound change in the distribution of forces in the Balkans. The collapse of the Ilinden-Preobrazhenie Uprising in Macedonia and Thrace in 1903 led to doubts about the success of revolutionary actions in the Balkans and shifted the centre of gravity to the vision of calming down the provinces by means of reforms introduced under the supervision of the European Great Powers. These events forced Bulgaria, undoubtedly helpless in the face of the dynamically changing situation, to redefine its Balkan policy. At the same time, the outbreak of the Russo-Japanese War in 1904 clearly revealed the Russian Tsar's focus on Asian and Far-Eastern matters and withdrawal from South-Eastern Europe. Austria-Hungary, devising visions of expansion towards Thessaloniki, tried to use this void to its advantage. The decision-makers in Vienna and Budapest were also forced to rethink the guidelines of their Balkan policy - in Serbia, so far economically and politically dependent, the May Coup took place in 1903. The pro-Habsburg House of Obrenović lost power, and Peter I Karađorđević and the new government were not so easy to control. Serbia ruled by the grandson of Black George, who took over power as a result of a bloody coup d'état, initially found itself isolated.

In these circumstances new concepts emerged of cooperation between South Slavic countries: Bulgaria, Serbia and Montenegro, under the patronage of Russia and against the interests of Austria-Hungary. The initiator of rapprochement talks was Bulgaria, which first approached Montenegro on this matter. To this end, Dimitar Rizov, a politician close to the Bulgarian Prince Ferdinand I Coburg, who had gained political experience as a trade agent in Skopje (1897-1899), was sent to Cetinje. Like the Montenegrin Prince Nicholas, Rizov believed the Obrenović dynasty to be the main obstacle to the rapprochement of "fraternal nations, derived from one tribe". ${ }^{14}$ They were wrong - it was the Macedonian issue that turned out to be the major point of contention. Montenegro was willing to cooperate with Bulgaria only on condition that Macedonia would be divided into spheres of influence. Meanwhile, the Bulgarians refused to change the position that the alliance should be based on supporting reforms which in time would lead to the autonomy of Macedonia. Neither side wanted to budge and the government in Sofia gave up cooperation with Cetinje at this stage, consoling itself that Serbia would be the key partner in the project, as a neighbour with much greater military and economic potential. ${ }^{15}$

14 С. Радоева,Димитьр Ризов - от Битоля до Берлин (1862-1918), София 2014, pp. 124-128.

15 “Доклад от българския дипломатически агент в Цетине Спас Константинович до министърпредседателя и министър на външните работи Рачо Петров, Цетине 14.05.1903” [in:] Отношенията между България и Черна гора 1878-1913 г. Сборник с документи, съст. М. Тодоракова, М. Каписода, София 2015, p. 213; “Шифрована телеграма от българския дипломатически агент в Цетине Андрей Тошев до княз Фердинанд I, Цетине 19.10.1905” [in:] Отношенията между България и Черна гора, рр. 257-260. 
The government in Belgrade, which counted on ending its international isolation after the May Coup, sought an agreement with Bulgaria, which was one of the few European countries that did not criticise the changes that followed the bloody overthrow of the House of Obrenović. The government in Sofia delegated the Bulgarian military attaché Hristo Hesapchiev as the negotiator, who in February 1904 was appointed the diplomatic agent in Belgrade. With time, he was joined by Rizov, who was valuable due to having close relations with the leaders of the Serbian government camp: the head of the People's Radical Party, Nikola Pašić, and the speaker of the Serbian National Assembly, Aca Stanojević. The Bulgarians spoke about a strictly defensive alliance, based on not allowing Austria-Hungary (treated by Belgrade as the main enemy of the South Slavs) to occupy Macedonia, supporting a programme of reforms in the region, and opening Bulgarian ports to Serbian goods. In short: Bulgaria was to treat the Habsburg Monarchy as an enemy, and Serbia was to accept the Bulgarian policy with regard to Macedonia. ${ }^{16}$

Serbia held a similar position to Montenegro in terms of solving Macedonian issues and was not prepared to abandon it easily. Pašić pushed for dividing spheres of influence on the territory of Turkey-in-Europe among three South Slavic countries. Kosovo and the Sanjak of Skopje (an area called by Serbs as "Old Serbia") were to become the sphere of Serbian influence, the rest of Macedonia and Adrianople Thrace — of Bulgarian one, and the Albanian territories - of Montenegrin one. The Serbs emphasised that the Vilayet of Kosovo should be incorporated into their state as compensation for the annexation of Eastern Rumelia by Bulgaria in 1885. The government in Belgrade also suggested introducing a provision that Russia would arbitrate in case of disagreements about the implementation of the terms of the alliance. ${ }^{17}$

However, the Bulgarian vision of the rapprochement won out and resulted in two treaties signed on 12 April (30 March) 1904. The first one was confidential - it established a military alliance, guaranteed support for the project of reforms in Macedonia and for attempts to expand it to Thrace, and declared counteracting attempts to occupy provinces of Turkey-in-Europe by the Great Powers. Out of the Serbian proposals, the mechanism of Russian arbitration on contentious matters was maintained, as were efforts to secure Montenegrin influence on Albanian territories. ${ }^{18}$ The other, publicised treaty focused on economic cooperation and working towards a customs

16 “Забелешке Николе Пашића о разговорима са бугарским отправником послова пуковника Хесапчијевим, Београд 11/23.02 - 19.02/3.03.1904, бр. 540” [in:] Документи о спољној политици Краљевине Србије 1903-1914, књ. 1, св. 1, прип. А. Раденић, ур. Р. Самарџић, Београд 1991, pp. 984-990; Е. Стателова, Р. Попов, В. Танкова, История на българската дипломация 1879-1913 2., София 1994, pp. 327-330; С. Радоева, Димитър Ризов - от Битоля до Берлин (1862-1918), pp. $128-130$.

17 От полковник Хасапчиев до Рачо Петров, Белград 11.0.3.1904, НБКМ-БИА, ф. 266 а.е. 25 л. 51-57; Е. Стателова, Р. Попов, В. Танкова, История на българската дипломаџия 1879-1913 г., pp. 332-336; Б. Попов ић, Дипломатска историја Србије, Београд 2010, pp. 495-496.

18 "Układ serbsko-bułgarski [zawarty w Belgradzie 30 marca / 12 kwietnia 1904]" [in:] Historia Bułgarii 1870-1915. Materiały źródtowe z komentarzami, vol. 1: Polityka międzynarodowa, eds. J. Rubacha, A. Malinowski, A. Giza, Warszawa 2006, pp. 81-82. 
union. ${ }^{19}$ The fact that the confidential document contained no description of spheres of influence should be regarded as a result of the tenacity of the Bulgarian side, which in this way did not want to recognise any part of the Macedonian territory as Serbian. The treaties were ratified by both parliaments on 12 May (29 April) 1904, and three days later a meeting was held between Prince Ferdinand I and King Peter I in Niš. All signs pointed to the Serbian-Bulgarian rapprochement becoming reality. ${ }^{20}$

The second half of 1904 brought about disappointment. In June, the efforts to include Montenegro in the project failed, and the Bulgarians blamed the Serbs for this, as the source of a leak which influenced Prince Nicholas to turn his back on the initiative. ${ }^{21}$ The government in Cetinje was also in conflict with Belgrade over Montenegrin migration to Serbia and the support shown by the Serbian government to the constitutional opposition in Cetinje. Although on 11 October (28 September) a Bulgarian-Serbian military convention was held, which was approved by both sides, in the end it was not enforced. The new government in Belgrade, in which in December 1904 Sava Grujić was replaced by Nikola Pašić, who was much more stubborn about Macedonian issues, refused to sign it. The end of 1904 passed in an atmosphere of colder Bulgarian-Serbian relations and the dismissal of the idea of a South Slavic alliance. ${ }^{22}$ In the following year, both sides returned to the starting point-1905 saw more Serbian activity in Macedonia and clashes between Bulgarian and Serbian chetas, which was the clearest sign that the alliance had failed. ${ }^{23}$

The following years showed that the project of the South Slavic alliance was built on very fragile foundations. In March 1907, a rumour started among diplomats that an attempt was being made to form a Balkan alliance (with the participation of Serbia, Montenegro, and Turkey) against Bulgaria. The rumour was quickly quashed, but the situation proved that there was tension among South-Slavic states. ${ }^{24}$ The British consul in Belgrade had a confidential conversation with Dimitar Rizov, who noted a clear impasse in relations with Serbia due to the rapprochement between Bulgaria and Austria-Hungary and the activities of Serbian chetas in Macedonia. Rizov, who had been one of the biggest enthusiasts of the 1904 treaties, admitted that he was

19 “Дружествен договор между Княжество България и Кралство Сърбия, Белград 30.03.1904” [in:] Сръбските интриги и коварства срещу България (1804-1914). Дипломатически документи, съст. Ц. Билярски, София 2009, pp. 192-193.

20 “Телеграма от княз Фердинанд до българския дипломатически агент в Сърбия, София [април 1904]" [in:] Сръбските интриги, pp. 196-197; Б. Боев, "Посещението на Сръбски крал и сръбско-българското сближение,” Списание на Българското икономическо дружество 1904, год. 8 , кн. 1 , р. 660.

21 Писмо от Българско дипломатическо агенство в Цетиние до Министерство на вънчните дела и изповеданията, Цетиние 18.06.1904, НБКМ-БИА, ф. 266 а.е. 25 л. 42а-45а.

22 К. Списаревски, Сръбско-българския митнически съюз: Принос към историята на сръбско-българското побратимяване, София 1906, pp. 29-30; Е. Стателова, Р. Попов, В. Танкова, История на българската дипломаџия 1879-1913 г., pp. 340-344; J. Rubacha, Butgarski sen o Bizancjum. Polityka Butgarii w latach 1878-1913, Warszawa 2004, s. 113.

23 ЦДА, ф. 331 к оп. 1 а.е. 144 , passim.

24 FO 371/202/288-316. 
considering his resignation from the position of the diplomatic agent in Belgrade, recognising the failure of his policy. ${ }^{25}$

While the rapprochement between Bulgaria and Serbia did not come to pass, some agreements survived in the economic sphere. In December 1904 the main provision of the second treaty of April (March) 1904, i.e. a customs union, was approved by the Serbian and Bulgarian National Assemblies. The union was to start on 14 (1) March 1906 and to last for 11 years - it provided not only for lifting customs on borders but also for a number of regulations facilitating the functioning of Bulgarian companies in Serbia and vice versa. Article 16 provided for work on a common currency and a system of measures and weights, as well as cooperation on pursuing deserters, executing court sentences and extradition. ${ }^{26}$

The object of the treaty was, first of all, to make Serbia independent from trade exchange with Austria-Hungary ( $80-88 \%$ of exports in the early $20^{\text {th }} \mathrm{C}$.), and Bulgaria from Turkey (around $20 \%$ at that time), as a result of transit of Serbian goods via Bulgarian ports in the Black Sea region (Varna, Burgas). The talks were being conducted in secret from the government in Vienna, but this did not last very long. Austria-Hungary decisively demanded that Serbia withdraw from the customs union on the pretext that it conflicted with the Serbian-Austrian-Hungarian trade agreement. The government in Belgrade refused, which led to Vienna's embargo on Serbian goods - the main Serbian exports, i.e. pigs, were stopped on the border for sanitary reasons. The position of Sofia seemed to be closer to Austria-Hungary in this conflict. Serbia, which felt insufficiently backed up by Bulgaria and concluded that it needed a much stronger supporter in the trade rivalry with Vienna, withdrew from the planned customs union. Initially, the government in Belgrade assumed that the customs war would end in exchange for Serbia abandoning the project. This was not the case. Serbian transit found its way via Turkey (Thessaloniki) and Romania (Brăila), and France replaced Austria-Hungary, both in terms of a ready market and a source of investment, loans, and weapon exports. This met with great disappointment of the government in Sofia, and the Bulgarian-Serbian relations became much colder again. ${ }^{27}$ This state continued until Bulgarian-Serbian negotiations regarding economic cooperation were revisited after Austria-Hungary annexed Bosnia and Herzegovina in 1909; the talks resulted e.g. in an agreement on the liquidation of Serbian schools in Macedonia. ${ }^{28}$ This rapprochement was one of the steps towards the Balkan alliance created in 1912.

25 Mr Whitehouse to Sir Edward Grey, Belgrade 4.03.1907, FO 371/202/306.

26 К. Списаревски, Сръбско-българския митнически съюз, pp. 51-61.

27 Ibid., pp. 32-39; W. Felczak, T. Wasilewski, Historia Jugosławii, Wrocław 1985, pp. 392393.

28 ЦДА ф. 331к оп. 1 a.e. 293, passim. 


\section{SOUTH SLAVIC HOPE}

Federalist concepts in the Balkans were at that time supported not only by South Slavic governments, but also by grassroots initiatives. In 1904 the students of the University of Sofia, led by the later writer and ethnologist Stiliyan Chilingirov, became very active in this area. Between 6 and 8 March (22-24 February) 1904, the Student Balkan Congress was organised in Sofia, which gathered together representatives of South Slavic nations: the Bulgarians, Serbs, Montenegrins, and Croats. The Greeks and Romanians, who had also been invited, did not reply to the invitation. As a result, the event took on a South Slavic character. The speeches given by the participants orbited around slogans of abandoning nationalisms and working towards a Balkan federation or confederation. The congress was attended, among others, by the later dictator of Bulgaria, Aleksandar Tsankov, and Boncho Boev. On 6 May (23 April), St. George's day, which was also the $100^{\text {th }}$ anniversary of the coronation of King Peter I Karađorđević, the second congress was organised, this time in Belgrade. The Serbs from the Slavic South Organisation took over the initiative; they postulated a union of the Serbs, Croats, Slovenians, and Bulgarians. During the congress, whose slogan was "South Slavs - unite!", various scenarios of building South Slavic State were discussed. On the one hand, there were voices calling for a union under the rule of King Peter I, which referred back to the projects from the 1860s. On the other hand, many students believed that building a unified state had to be accompanied by overturning the monarchy and proclaiming a republic. The third Student Balkan Congress also took place in 1904 in Belgrade, but when the Bulgarian-Serbian talks ended in a fiasco, the initiative lost its significance. ${ }^{29}$

During the first Student Balkan Congress, one of the main speakers was Boncho Boev, and his two speeches were published in the Journal of the Bulgarian Economic Society, of which he was the editor, in 1904: The Visit of the King of Serbia and the Serbian-Bulgarian Rapprochement (Посещението на Сръбски крал и сръбскобългарското сближение) and The Balkan Federation as an Ideal of the Bulgarian-Serb Youth (Балканската федераџия като идеал на сръбско-българската младеж). The texts reflect Boev's federalist views, which during this period, due to the Bulgarian-Serbian rapprochement, emphasised the prospects of a South Slavic union.

The starting point for Boncho Boev's reflections was the conviction that the period of 25 years after the Berlin Congress had been wasted in terms of achieving the main national goals by South Slavic states: the liberation from the Turkish rule of all Bulgarians and Serbs, i.e. the territories of Macedonia, Thrace, and Kosovo. Bulgaria and Serbia were unable to take advantage of the historical moments; they were politically and militarily too weak "with their empty arsenals and small arms budgets,

29 Б. Бо ев, “Балканската федерация като идеал на сръбско-българската младеж,” Списание на Българското икономическо дружество 1904, год. 8, кн. 2, р. 101; И. Орманджи ев, Федерация на балканските народи, pp. 99-101; К. Манчев, Сърбия и сръбско-българските отношения 18042010, София 2014, p. 206. 
prepared just to appease the general public who cannot even read numbers". ${ }^{30}$ Boev reproached Bulgaria for spending 600 million leva since the rebirth of the state, and Serbia for spending 400 million, which in no way translated into military or political potential. By focusing on mutual conflicts (both internal and external), the governments in Sofia and Belgrade caused a situation where other states started to play the key role in Macedonia and Kosovo. ${ }^{31}$ Boev was naturally referring to the signatories of the Mürzsteg programme of 1903, which proposed that representatives of AustriaHungary, Russia, Italy, Great Britain, and France would, through their civil agents, oversee the Macedonian reform of the local gendarmerie, finances, judiciary, and administration. $^{32}$

Boev had an even worse opinion about the economic achievements of the two largest South Slavic states. Every year, the budgets ended in deficit, public debt continued to grow, the industry practically did not exist, the only exports were fruits in Bulgaria's case and pigs in Serbia's, and the neighbouring countries, Austria-Hungary and Turkey, profited from the trade exchange. The Serbs were fully economically dependent on its northern neighbour, "losing its economic face in the sea of Habsburg economy". Swine and plums, the two most important Serbian exports, were sold in Hungary, and then distributed in the world under a Hungarian label. Serbian cereal was ground in Hungarian mills and the bread baked with it was sold in the West. Serbia was not an exception in South-Eastern Europe. Only 12\% of the trade exchange in the region took place among Balkan states; the majority of the transactions were made with Germany, Austria-Hungary, and Great Britain. From Europe, South Slavs imported textiles, metals and metal products, colonial goods, leather and leatherware, chemical products, glass, and machinery, while the export was mainly limited to unprocessed foods and livestock. ${ }^{33}$ In short: Serbia and Bulgaria sold very cheap raw materials, which were processed by the Great Powers and sold for a much higher price, while also paying a fortune for Western products produced from materials imported from the Balkans. Boev noted the particular cunning of the government in Vienna, which kept strengthening the Serbs' conviction that there was no alternative to the everlasting protection of the Habsburg monarchy. He blamed Austria-Hungary for provoking conflicts between Serbia and the Ottoman Empire (so that trade could not be directed through the port in Thessaloniki) as well as Bulgaria (which also had the consequence of limiting Belgrade's role as Piedmont of the South Slavs). Boev called these disputes "small affairs" (appointing diplomatic agents and vladykas, opening schools and Orthodox churches in Macedonia), which in his opinion were instigated by the Great Powers to maintain the status quo in the region. European capitals had a vested interest in keeping the Balkans economically broken up because they earned millions from trading with the states in the region. ${ }^{34}$ The Bulgarian economist also

30 Б. Боев, Посещението на Сръбски крал, р. 656.

31 Ibid., pp. 656-657.

32 See N. Akhund, "Stabilizing a Crisis and the Mürzsteg Agreement of 1903. International Efforts to Bring Peace to Macedonia," Hungarian Historical Review 2014, no. 3, pp. 587-608.

33 Б. Бое в, Балканската федерация, pp. 109-110.

34 Ibid., p. 106. 
saw the roots of South Slavs' economic weakness in education: Bulgarian and Serbian schools did not prepare people for functioning on the labour market in the early $20^{\text {th }} \mathrm{C}$., and sent out "a host of undereducated clerks, philosophers, philologists, lawyers, and economists", which increased the malfunction of South Slavic economies. ${ }^{35}$

Although Boncho Boev devoted a lot of space to criticising the situation in the Balkans at the time, he also equally focused on how to change it to the advantage of the South Slavs. The first step was to be Serbia's economic emancipation; this could be achieved in cooperation with Bulgaria, which offered railway transport and Black Sea ports, "which would be a window on the world for products from Serbia". Boev calculated that 6,000-7,000 freight cars with Serbian exports could arrive in Varna and Burgas annually. ${ }^{36}$ In a longer term, the economic integration of the two South Slavic states would lead to creating an influential economic territory and achieving the status of an important entity, independent from foreign capital and with its own investment funds. Just as individual cities or provinces did not have the suitable capital to make the necessary investments in this area, neither did small states. Small economic entities equalled to Boev with small financial resources and insufficient capabilities in the field of economy. The economy of a united economic territory was to be based on producing livestock and foodstuffs by the Serbs and textiles and clothes by the Bulgarians. With time, as the federation would grow to include other Balkan states, these would also include growing vegetables and producing olive oil by the Greeks and involving the other Balkan nations (the Romanians in the first place) in exporting and trading these goods. As Boev wrote: "The diversity of the great territories, and in consequence, the wealth of raw materials, including the ones harvested in the mountains, is the Balkans' asset, and an area for agreement between Balkan nations". ${ }^{37}$

The economic union and creating a common market were supposed to become, in a longer term, the basis for a political and national union. ${ }^{38}$ Boev emphasised many times that the foundation of cooperation between the Serbs and the Bulgarians was the fact that these were "two fraternal nations living in identical cultural and economic conditions, and two comparably small states should protect each other against larger ones". ${ }^{39}$ The Bulgarian economist believed that "the union of the two largest South Slavic elements could take place without pathos and great diplomatic declarations, because common economic interests are the most stable foundation for creating alliances" ${ }^{40}$ Boev was aware that there were separate national cultures, the Serbian and the Bulgarian one, but he believed that this was secondary to the economic benefits that the establishment of one state could bring. ${ }^{41}$ The South Slavs could emulate states such as Switzerland, Great Britain or Belgium, which had never been ethni-

35 Б. Боев, Посещението на Сръбски крал, pp. 657-658.

36 Ibid., pp. 660-661.

37 Б. Боев, Балканската федерация, р. 106.

38 Ibid., pp. 104-106; Б. Боев, Посещението на Сръбски крал, pp. 658-659.

39 Б. Боев, Посещението на Сръбски крал, р. 656.

40 Ibid., p. 661.

41 Б. Боев, Балканската федерачия, pp. 102-103. 
cally homogeneous but over time created one nation. He emphasised that Bulgaria and Serbia were basically on the same level of development: at the stage of transferring from an agriculture-based economy to an industry-based economy; they also had a similar level of sales. Somewhat in the spirit of Marxism, he noted that classes and representatives of the same occupation among South Slavic nations could be closer to each other than representatives of one nation, divided socially and economically. ${ }^{42}$ Boev did not hide that his inspiration was derived from leftist ideas - he emphasised that the next stage of the development of the federation would be the collapse of monarchs, who focused solely on warfare. Then, he anticipated the development of "state socialism" (clearly stating that he did not mean pure socialism), based on the model of a welfare and protectionist state with a broad labour market and a modern administration - a state which would guarantee the development of civil liberties and equal rights and reject "reactionist chauvinism" ${ }^{43}$. It may be surprising that these words were written by a thoroughbred capitalist, but we should remember about the context in which these texts were created; they were addressed to leftist student circles.

Boev had no illusions that the main source of conflict between the Serbs and the Bulgarians was the Macedonian question. He emphasised that the disagreement existed only in the heads of politicians on both sides, and the ordinary Serbs and Bulgarians completely failed to understand it. The economist noted with disappointment that so far, no decisive supporter of the idea of federalism had appeared on the Bulgarian political scene. Boev wrote about the Bulgarian-Serbian conflict as a millenniumlong curse, the lifting of which was a great challenge for the contemporary people: "We have wasted 25 years attempting to achieve our goals, acting not in the spirit of a real policy but in the spirit of ideas formulated by enthusiasts of Dušan and Samuil and other dreamers about kingdoms and empires" ${ }^{44} \mathrm{He}$ believed that the union would lead to neutralising the Macedonian antagonism, because it would mean that Sofia and Belgrade would join forces to attach this area to the common South Slavic state. The Bulgarian economist did not go into detail either with regard to the way of controlling the territories which remained under the Ottoman rule, or the political organisation of the state and Macedonia's place in it, believing that these were matters secondary to the economic ones. ${ }^{45} \mathrm{He}$ did, however, outline the borders of the South Slavic federation surrounded by three seas (the Black, Aegean, and Adriatic Seas), which functioned in peaceful conditions and respected the idea of pacifism. Economy again came to the forefront. Controlling the western, eastern and southern coasts of the Balkans would mean for the South Slavic state access to the cheapest means of transporting goods, as well as European and African trade routes. The vision of peace is equal to Boev with freeing up the funds so far designated to keeping an army; he noted that 100 million leva was spent annually on this area by Bulgaria and Serbia.

42 Ibid., pp. 106-107.

43 Ibid., pp. 111-113.

44 Boev is referring to the medieval rulers, Serbian emperor Stefan Dušan and Bulgarian emperor Samuil - symbols of the Greater Serbia and Greater Bulgaria ideals. Б. Боев, Посещението на Сръбски крал, pp. 658-660.

45 Ibid., p. 661; Б. Боев, Балканската федерация, рр. 101-102. 
The economist saw the union as a prospect of saving half of this sum each year, and at the same time shifting 50,000 soldiers to farm and factory work, which - according to his estimates - would bring in an additional 15-20 million leva annually. ${ }^{46}$

In Boncho Boev's concepts the South Slavic union was just a stage in the process of creating a supra-national Balkan federation with the participation of "the Turks, Greeks, and Bulgarians, the Vlachs and the Serbs, the Albanians, Koutsovlachs and Macedonians, followers of Exarchate and Patriarchate, Catholics, Uniats and Protestants, the oppressed and the free". ${ }^{47}$ The Bulgarian economist noted that this idea had been realised in the past - the Balkans had been united under the Turkish rule for five centuries. However, he believed the model of unity based on conquest and violence to be impermanent; true stability could be built on "common material and spiritual interests". He thought that the Balkan union was inevitable; however, as he emphasised, it could take place either by means of a new yoke, under the Austrian or Russian rule, or by means of an independent federation. ${ }^{48}$ "Only when Bulgaria will sink in the Russian sea, and Serbian Sava will be decorated with St. Stephen's crown, will we wake up. This is our joint task, to realise that we have one common interest," warned Boev. ${ }^{49}$

\section{CONCLUSION}

Boev's concepts were naive in many places - he did not see that both the differences between the Serbians and the Bulgarians and the conflict over Macedonia were so large that it was very unlikely to find South Slavic agreement in the form he proposed. This was perfectly illustrated by the negotiations carried out in 1904 between Sofia and Belgrade: even signing specific contracts on a defence alliance and customs union, in which both states made some concessions, did not lead to removing these animosities. The Serbs continued to want to divide spheres of influence in Macedonia and fight against Austria-Hungary, and the Bulgarians continued to treat Macedonia as a uniform territory inhabited by the Bulgarians and saw Vienna as a potential ally. Boev overestimated the key role of economy in the potential union, naively believing that a Serb and a Bulgarian with a full stomach would forget about great national ambitions: Stefan Dušan and San Stefano. Contrary to what the Bulgarian economist assumed, not only politicians, but both societies were involved in the dispute and supported the activities of their respective governments. Boev focused too much on describing current economic problems and the economic benefits which would come from a unified South Slavic state (over time expanded to the other Balkan states), but he did not address a number of questions which were much more important at that

\footnotetext{
46 Б. Бо в, Балканската федерация, р. 110.

47 Ibid., p. 103.

48 Ibid.

49 Ibid., pp. 110-111.
} 
time. How to bring about including Macedonia in the planned federation: through war, an insurrection, a union modelled on East Rumelia in 1885? How to politically organise the new Bulgarian-Serbian, and then Bulgarian-Serbian-Macedonian, state? How to guarantee the equal status of all the states in the federation? How to solve the dispute about the nationality of the Macedonian Slavs? Boev did not even try to address these difficult questions. The attempts to form a Bulgarian-Serbian alliance in 1904 were based on similarly weak foundations; the initiative of the Student Balkan Congresses turned out to be even shorter-lived. These problems also surfaced during the functioning of the Balkan League in 1912, and they caused what we could call a fraternal war among the allies a year later.

Nevertheless, in the times when the "Balkan powder keg" more and more frequently threatened to explode, everything seemed to be leading to a conflict, and the fraternal Balkan nations burnt with more and more hatred towards one another, the voice of Boncho Boev, calling for unity in order to avoid the catastrophe of fraternal wars, was a valuable one. We also cannot deny the logic of the Bulgarian economist's reasoning, which is best illustrated by the modern times. The process of political unification preceded by economic integration, proposed by Boev, is being implemented in a different form in the present-day European Union.

In comparison to Serbian intellectuals and politicians, in Bulgaria the ideas of South Slavic cooperation were on the margins of political thought. Proclaimed also by socialists, the milieu of the insignificant Radical Democratic Party, and some activists of the Internal Macedonian Revolutionary Organisation (IMRO), they did not emphasise the South Slavic element, and instead proposed organising the Balkans in the form of a federation, with the participation of non-Slavic nations inhabiting the region (the Greeks, Romanians, and Turks). This is also visible in Boncho Boev's thought, for whom the South Slavic state was only a temporary stage. The domination of the idea of Balkan federalism over Yugoslavism and the virtual replacement of the latter in the Bulgarian political thought was not only the result of the conflict with the Serbs, which had been gathering speed since 1878. Already in the first half of the $19^{\text {th }} \mathrm{C}$. the geographical distance from the other South Slavs, the initial fears of being absorbed by the more advanced Serbian national movement, and closer contacts with Russia than with the Serbs, Croats and Slovenians pushed the Bulgarians to the margin of Illyrian concepts, which later evolved into Yugoslavism. ${ }^{50}$

50 Н. Кайчев, Илирия от Варна до Вилах. Хърватското национално възраждане, сърбите и българите (до 1848 г.), София 2015, pp. 205-220. 


\section{BIBLIOGRAPHY}

\section{Sources}

\section{Archival sources}

Foreign Office Archives, Public Record Office, London

FO: 371 (Political Departments: General Correspondence from 1906-1966).

Bulgarian Historical Archive in the SS. Cyril and Methodius National Library in Sofia (Народна Библиотека “Св. Св. Кирил и Методи” - Български исторически архив, НБКМ-БИА) ф. 266 (Рачо Петров).

Central State Archives in Sofia (Централен държавен архив, ЦДА) ф. 321к (Дипломатическо агентство в Битола).

\section{Printed sources}

Historia Bułgarii 1870-1915. Materiały źródłowe z komentarzami, vol. 1: Polityka międzynarodowa, eds. J. Rubacha, A. Malinowski, A. Giza, Warszawa 2006.

Боев, Б., “Посещението на Сръбски крал и сръбско-българското сближение,” Сnисание на Българското икономическо дружество 1904, год. 8, кн. 1, pp. 655-662.

Боев, Б., “Балканската федерация като идеал на сръбско-българската младеж,” Списание на Българското икономическо дружество 1904, год. 8, кн. 2, pp. 101-113.

Документи о спољној политици Краљевине Србије 1903-1914, књ. 1, св. 1, прип. А. Раденић, ур. Р. Самарџић, Београд 1991.

Отношенията между България и Черна гора 1878-1913 г. Сборник с документи, съст. М. Тодоракова, М. Каписода, София 2015.

Списаревски, К., Сръбско-българския митнически съюз: Принос към историята на сръбско-българското побратимяване, София 1906.

Сръбските интриги и коварства срещу България (1804-1914). Дипломатически документи, съст. Ц. Билярски, София 2009.

\section{Literature}

Akhund, N., "Stabilizing a Crisis and the Mürzsteg Agreement of 1903: International Efforts to Bring Peace to Macedonia," Hungarian Historical Review 2014, no. 3, pp. 587-608.

Cetnarowicz, A., "Wkład Polaków w kształtowaniu się idei jedności wśród Słowian południowych," Studia Polono-Danubiana et Balcanica 1995, vol. 7, pp. 33-44.

Felczak, W., Wasilewski, T., Historia Jugosławii, Wrocław 1985.

Giza, A., Idea jugoslawizmu w latach 1800-1918, Szczecin 1992.

Hornyák, Á., "The Balkan Federation 1866-1948," Bulgarian Historical Review 2007, vol. 35 , no. $1-2$, pp. $217-232$. 
Rubacha, J., Butgarski sen o Bizancjum. Polityka Butgarii w latach 1878-1913, Warszawa 2004.

Skowronek, J., Sprzymierzeńcy narodów bałkańskich, Warszawa 1983.

Stavrianos, L. S., Balkan Federation. A History of the Movement toward Balkan Unity in Modern Times, Northampton 1944.

Stawowy-Kawka, I., "Miejsce Macedonii w koncepcjach federacji bałkańskiej" [in:] Ku zjednoczonej Europie. Studia nad Europa Środkowa i Poludniowo-Wschodnia w XIX i XX wieku, eds. I. Stawowy-Kawka, W. Rojek, Kraków 1997, pp. 83-98.

Znamierowska-Rakk, E., "Z dziejów bałkańskich koncepcji federacyjnych (od schyłku XVIII w. do końca I wojny światowej)," Studia z Dziejów Rosji i Europy Środkowo-Wschodniej 2000, vol. 35, pp. 5-23.

Żurek, P., Czarnogórcy i Serbowie w rosyjskiej polityce księcia Adama Jerzego Czartoryskiego (1802-1806), Kraków 2009.

Аврамов, Р., Комуналният капитализъм. Из българското стопанско минало, т. 2, София 2007.

България 20 век. Алманах, съст. Ф. Панайотов, София 1999.

Голяма енциклопедия България, т. 1: А-Бъл, ред. В. Гюзелев, София 2011.

Екмечић, М., Стварање Југославије 1790-1918, Београд 1989.

Енчев, В., “Югославската идея сред южните славяни през XIX и XX век,” Актуални проблеми, аспекти и перспективи на международните отношения 2010, т. 2, pp. 318-333.

Кайчев, Н., Илирия от Варна до Вилах. Хърватското наџионално възраждане, сърбите и българите (до 1848 г.), София 2015.

Лалков, М., От надежда към Разочерование, идеята за федерация в балканския югоизток, София 1994.

Манчев, К., Сърбия и сръбско-българските отношения 1804-2010, София 2014.

Орманджиев, И., Федерачия на балканските народи: Идеи и пречки, София 1947.

Поповић, Б., Дипломатска историја Србије, Београд 2010.

Радоева, С., Димитър Ризов - от Битоля до Берлин (1862-1918), София 2014.

Стателова, Е., Попов, Р., Танкова, В., История на българската дипломаиия 18791913 г., София 1994.

Стоянов, Ц., Федеративната идея в българо-сръбските отношения, София 1919.

Шишић, Ф., Југословенска мисао. Историја идеје југословенског народног уједињења и ослобођења од 1790-1918, Београд 1937. 